\title{
USPOREDBA USAMLJENOSTI ADOLESCENATA ISTARIJIH OSOBA U USTANOVAMA SOCIJALNE SKRBI
}

\author{
Danica Železnik ${ }^{1,2}$, Ružica Kanisek², Uroš Železnik ${ }^{1,4}$ \\ ${ }^{1}$ Visoka šola za zdravstvene vede Slovenj Gradec, Slovenija \\ ${ }^{2}$ Alma Mater Europaea, ECM, Slovenija \\ ${ }^{3}$ Dom za starije i nemoćne osobe Osijek, Hrvatska \\ ${ }^{4}$ Dom zdravlja Ptuj, Slovenija \\ Rad je primljen 16.08. 2016. R Rad je recenziran 26.08.2016. Rad je prihvaćen 09.09.2016.
}

\section{SAŽETAK}

UVOD:Usamljenost se često opisuje kao neugodna, bolna, anksiozna potreba za drugom osobom ili osobama. To je ljudsko iskustvo koje u većoj ili manjoj mjeri dožive svi ljudi u nekom životnom razdoblju.

CILJ: Cilj je istraživanja utvrditi postoje li razlike u percepciji usamljenosti između adolescenta smještenih u ustanovi za djecu i mlade i osoba starije životne dobi smještenih u domu za starije osobe.

METODE I ISPITANICI: U ovom istraživanju je sudjelovalo ukupno 70 ispitanika, od kojih je 25 korisnika Dječjeg doma Klasje u Osijeku dobi od 12 - 20 godina i 45 korisnika Doma za starije i nemoćne osobe u Osijeku dobi od 67 godina i više. Instrument istraživanja je anonimni anketni upitnik. Razlike između ocjena usamljenosti prema ustanovama testirane su Mann Whitney testom, a prema razlogu smještaja u dom Kruskal Wallis testom.

REZULTATI: Od ukupnog broja ispitanika 67,1 \% su žene, a 32,9 \% muškarci. S nepotpunom osnovnom školom je 32,9 \% ispitanika, osnovnu školu ili srednju ima završenu 60 \% ispitanika, dok samo 7,1 \% ispitanika ima završenu visoku školu ili fakultet.

Rezultati ukazuju na to da se najveća razlika između dvije skupine očituje kroz socijalnu podršku i kvalitetu odnosa među skupinama, a nešto manje kroz emocionalna stajališta.

RASPRAVA I ZAKLJUČCI: Iz istraživanja se može zaključiti da je nešto manja usamljenost među adolescentima nego među starijim osobama u ustanovama. Naglasak ovog istraživanja bi bio, da bi se trebalo više posvetiti pažnje individualnim potrebama mladih i starih osoba u svrhu uključivanja u zajedničke programe prema njihovim mogućnostima.

Ključne riječi: adolescenti, starije osobe, usamljenost

Osoba za razmjenu informacija:

izv. prof. dr. Danica Železnik

zeleznik.danica@gmail.com

\section{UVOD}

Osnovna ljudska potreba je potreba za pripadanjem i ona je temeljni ljudski motiv koji pretpostavlja da sva ljudska bića teže formiranju i održavanju ugodnog i trajnog intrepersonalnog odnosa. Socijalni odnosi koji nas ispunjavaju zadovoljstvom, u kojima uspijemo zadovoljiti osnovne socijalne potrebe i svoju potrebu za intimnošću čine nas ispunjenim, zadovoljnim i na osnovu toga određujemo naše ponašanje u odnosu na druge (1).
Tijekom adolescencije posebno je važno druženje, što utječe na identitet adolescenata i pripadnost neki grupi. Adolescencija se najčešće doživljava kao veseli i vrlo aktivni period, kojeg karakteriziraju česta druženja te intenzivni socijalni odnosi, ali neki adolescenti žive u ustanovama socijalne skrbi i žive na drugačiji način, te zbog toga mogu osjećati usamljenost.

Sa starenjem, neizbježno je da ljudi gube vezu sa svojim prijateljskim mrežama te da je teže pokrenuti 
nova prijateljstva i izgraditi nova umrežavanja. Koncept socijalne mreže se obično opisuje kao mreža koja se sastoji od određene osobe i svih ljudi koje ona poznaje ili s njima redovito dolazi u interakciju (2).

Dosadašnja istraživanja o ispitivanju socijalne mreže i usamljenosti nisu dala konzistentne rezultate. Dok neka pokazuju postojanja negativne povezanosti, u drugima nije pronađen takav odnos. Takvi rezultati upućuju da usamljenost ima više veze s kvalitetom socijalnih kontakata nego s njihovom dostupnošću i učestalošću, pa to podupire tvrdnju da se ljudi osjećaju manje usamljeni kada su zadovoljni svojom socijalnom mrežom. Kada doživljaju intimnosti i bliskosti u interpersonalnim odnosima, znaju da mogu računati na podršku osoba iz svoje socijalne mreže, te kada su uključeni u socijalnu mrežu čiji su članovi visoko međusobno povezani (2). Poznato je, da pojedinac može biti usamljen i kada se nalazi u blizini drugih ljudi, te da za osjećaj usamljenosti nije bitna fizička prisutnost drugih osoba.

Socijalna podrška je jedan od važnijih pokazatelja kvalitete socijalne mreže, jer je vjerojatnije da će osoba, kada bude potrebno, dobiti pomoć i empatiju od članova svoje socijalne mreže koja im daje osjećaj pripadanja i zajedništva. Iz znanstvene literature izlazi, da je pozornost socijalnim čimbenicima pokazala da imaju utjecaj na rizik od smrtnosti. Biti društveno povezan osim utjecaja na psihološko i emocionalno blagostanje ima i značajan pozitivan utjecaj na fizičku dobrobit i ukupno dugovječnost $(3,4)$. Nedostatak društvenih veza je također bio povezan s štetnim zdravstvenim ishodima u prethodnim istraživanjima (5). Nedostatak u socijalnim odnosima i subjektivna reakcija na to rezultiraju emocionalnim doživljajem kojeg nazivamo usamljenost. U slučaju nezadovoljene potrebe javljaju se različite poteškoće: medicinske, psihološke ili poteškoće u ponašanju kojima prethode vrlo neugodna emocionalna stanja. Pojam usamljenosti podrazumijeva dulje stanje emocionalne uznemirenosti koja nastaje kada se osoba osjeća otuđeno, neshvaćeno i odbačeno od drugih ili joj nedostaju socijalni partneri za željene aktivnosti, posebice za aktivnosti koje pružaju osjećaj socijalne integracije i mogućnost emocionalne bliskosti (5). Široko je prihvaćeno da je depresija koja se po prvi put pojavljuje kasnije u životu u pravilu povezana s problemima tjelesnog zdravlja koji se javljaju sa starenjem, te da starija osoba koja je dobrog zdravlja i nema povijest ranijih depresivnih epizoda ima nizak rizik za pojavu depresije (6).

S obzirom da je usamljenost emocijama vezana za percepciju uspješnosti ostvarivanja i sudjelovanja u socijalnim interakcijama, postavlja se pitanje kada se javlja. Do nedavno istraživanje tog fenomena bilo je usmjereno na adolescente i odraslu dob, međutim osjećaj usamljenosti javlja se već kod mlađe djece. Asher i sur. u svom istraživanju navode da kod opisa osjećaja usamljenosti djece od trećeg do osmog razreda i odraslih nema razlike. Obje dobne skupine to neugodno socijalno iskustvo opisuju istim pridjevima. Pretpostavka Sullivana počiva na činjenici da dijete osjeća emocionalnu potrebu za druženjem vrlo rano i da je to vrijeme formiranja prvih socijalnih odnosa. Ti prvi socijalni odnosi temelje se na potrebi za pripadanjem i uključivanjem u vršnjačku zajednicu (7). U predadolescenciji i adolescenciji socijalni odnosi motivirani su potrebom za intimnošću. Obje socijalne potrebe, potreba za pripadanjem i potreba za intimnošću, ostvaruju se i zadovoljavaju u interakciji s vršnjacima $(7,8)$. Prema tome sasvim je opravdano o usamljenosti govoriti i prije adolescencije i to osobito u kontekstu vršnjačke interakcije.

Većina istraživanja uvjerljivo navodi da institucionalizacija djece ima negativan utjecaj na njihov razvoj, rast i zdravlje (9), ali institucionalizirana briga postaje jedina mogućnost za onu djecu, koja živi u siromaštvu i bespomoćnosti. Pronađeno je da djeca u institucionalnoj skrbi imaju veće emocionalne probleme $(10,11)$. Oni imaju tendenciju i da se emocionalno povlače (12) kao i iskustvo emocionalne usamljenosti $(12,14)$. Rezultati istraživanja Padmaja i sur. pokazuju visoki stupanj depresije i nisko blagostanje djeca u institucijama, kao što je također potvrđeno drugim istraživanjima. Prema njima, čak i ako je institucija je u stanju smanjiti psihopatologiju, to ne jamči dobrobit i dobru kvalitetu života $(15,16)$. 
Usamljenost se često povezuje i sa starijom dobi, te je identificirana kao jedan od čimbenika rizika koji vodi do ozbiljnih zdravstvenih problema. Isto tako predstavlja jedan od faktora koji vode do depresije, te je značajan uzrok suicida i pokušaja suicida (17). Pokazalo se, da su starije osobe koje žive u institucijama pod većim rizikom za ove poteškoće te da ih je približno $40 \%$ pogođeno značajnim simptomima depresivnosti (6).

Osim što može prouzročiti niz zdravstvenih problema, usamljenost je povezana sa slabijom psihološkom prilagodbom, te nezadovoljstvom postojećih odnosa unutar obitelji i društva. Kako god to tumačili postoji veza između starenja i usamljenosti. Postoji svjesnost fenomena usamljenosti starih osoba i nekih dokaza da zdravstvena njega može biti djelotvorna u ublažavanju samoće i njenih štetnih posljedica. Starenje može utjecati na usamljenost na više načina. Produžen osjećaj usamljenosti može dovesti do stvaranja loše slike o samome sebi i do nemogućnosti da se nosi s neizbježnim gubitcima koji se javljaju kasnije u životu kao što su: smrt supružnika, prijatelja, društvena distanciranost nakon umirovljenja su neki od sveprisutnih životnih događaja koji mogu doprinijeti usamljenosti kod starijih osoba. Iskustvo usamljenosti može se doživjeti na različite načine, bilo kao posljedica samačkog života, manjka obiteljskih veza ili nemogućnost aktivnog sudjelovanja $\mathrm{u}$ aktivnostima lokalne zajednice. Kada se usamljenost javlja u kombinaciji sa nekom vrstom tjelesnog oštećenja, često se javlja osjećaj beznađa i depresije $(18,40)$.

Usporedba usamljenih i neusamljenih osoba rezultirala je popisom pridjeva koji se razlikuju u dvije skupine. Usamljeni ljudi imaju niže samopoštovanje od neusamljenih, skloni su depresivnim i anksioznim stanjima, postoji veza između depresije, usamljenosti i samopoštovanja kod starih ljudi i kod mlađih $(19,42)$. Ta neugodna emocija s kojom kreću u interakciju dovodi do neprijateljskog raspoloženja prema drugima, što nailazi na neodobravanje. U takvim slučajevima društvo takvu osobu odbacuje što dovodi do socijalnog povlačenja i usamljenosti $(9,42)$.
Osjećaji, pa tako i usamljenost, imaju značajnu ulogu u ponašanju pojedinca. Osjećaj neprihvaćenosti, neadekvatnosti i socijalne izoliranosti rezultira negativnim oblicima ponašanja. Agresivno ponašanje socijalno je negativno i neprihvatljivo. Neadekvatni odnosi s okolinom potiču agresivno ponašanje Odnos kvalitete interakcije, osjećaja usamljenosti i ponašanja postaje međuovisan (19).

Depresija i anksioznost povezani su s usamljenošću kao što su povezane i razne zdravstvene poteškoće i problemi. Međuljudske i društvene korelacije usamljenosti uključuju gubitak partnera i smanjenje društvene aktivnosti $(15,16,18,20,22-26)$.

Cilj ovog istraživanja bio je utvrditi postoje li razlike u percepciji usamljenosti između adolescenta smještenih u ustanovi za djecu i mlade i osoba starije životne dobi smještenih u domu za starije osobe.

\section{ISPITANICI I METODE}

U ovom istraživanju sudjelovalo je ukupno 70 ispitanika, od kojih je 25 korisnika Dječjeg doma Klasje u Osijeku, Republika Hrvatska, dobi od 12 - 20 godina i 45 korisnika Doma za starije i nemoćne osobe u Osijeku, Republika Hrvatska, dobi od 67 godina više. Kriterij za izbor ispitanika je dob, uz uvjet da su svi ispitanici u mogućnosti odgovarati na pitanja samostalno. Svaki ispitanik je upoznat sa ciljem i svrhom istraživanja, te je dao svoj pristanak za sudjelovanje. Za korisnike Dječjeg doma Klasje suglasnost se dobila od Ministarstva socijalne politike i mladih Republike Hrvatske.

Glavni instrument istraživanja bio je anonimni anketni upitnik koji se sastoji od dva dijela. Prvi dio upitnika sastoji se od šest pitanja u kojima ispitanici navode svoju dob, spol, mjesto provođenja istraživanja , stupanj obrazovanja ispitanika, razlog smještaja u ustanovu.

U drugom dijelu upitnika korištena je R-UCLA skala usamljenosti s 20 tvrdnji, a ispitanici su trebali za svaku tvrdnju odabrati koliko se često osjećaju usamljeni u skladu s navedenom tvrdnjom, odnosno u kojoj se mjeri određena tvrdnja odnosi ili ne odnosi na njih. Ispitanicima su za svaku od navedenih tvrdnji ponuđene četiri mogućnosti: 1 - nikada, 2 - rijetko, 3 - ponekad i 4 - često (30). Od ispitanika 
je traženo da se izjasne samo za jedan odgovor na upit o usamljenosti. Za konačnu ocjenu devet pitanja $(1,5,6,9,10,15,16,19,20)$ se boduje obrnuto, a veći broj odražava veći stupanj usamljenosti.

$\mathrm{Na}$ našem uzorku koeficijent pouzdanosti Cronbach Alpha, iznosi 0,890., za ispitanike Dječjeg doma Klasje 0,709 a za ispitanike Doma za starije i nemoćne 0,927 .

\section{Statističke metode obrade podataka}

Normalna raspodjela testirana je Kolmogorov-Smirnovljevim testom. Srednje vrijednosti kontinuiranih varijabli izražene su medijanom i interkvartalnim rasponom. Nominalni pokazatelji

prikazani su apsolutnim i relativnim brojem. Razlike među kategoričkim varijablama testirane su Fisher-ovim egzaktnim testom. Razlike između ocjena usamljenosti prema ustanovama testirane su Mann Whitney testom, a prema razlogu smještaja u dom Kruskal Wallis testom. Ocjena povezanosti dana je Spearmanovim koeficijentom korelacije. Rabljeni su izvorno pisani programi za baze podataka te statistički paket SPSS for Windows (inačica 17.0, Carry, NY, SAD), uz razinu značajnosti $\alpha=0.05$.

\section{REZULTATI}

Istraživanje je provedeno na 70 ispitanika, od kojih je $64 \%$ štićenika Doma za starije i nemoćne osobe, a $36 \%$ štićenika smještenih u Dječji dom Klasje u Osijeku. Srednja dob starijih ispitanika je 81 godina (interkvartilnog raspona 77 - 84,5 godina), u rasponu od najmanje 67 godina i najviše 94 godine. Adolescenti su srednje dobi 15 godina (interkvartilnog raspona 15 - 16 godina), u rasponu od 12 do 20 godina.

Duljina smještaja u ustanovu starijih ispitanika je 4 godine (interkvartilnog raspona $2-7$ godina), u rasponu od 0 do 29 godina, a mladih 2 godine (interkvartilnog raspona 0 - 6 godina), od najmanje jedne do najviše 10 godina (Tablica 1 ).
Tablica 1. Duljina boravka ispitanika u ustanovi

\begin{tabular}{lccc}
\hline & \multicolumn{3}{c}{ Skupine } \\
\cline { 2 - 3 } & Dom za starije i nemoćne & Dječji dom Klasje \\
\hline $\begin{array}{l}\text { Duljina boravka u } \\
\text { ustanovi; M (IR) }\end{array}$ & $4(2-7)$ & $2(0-6)$ & 0,029 \\
\hline
\end{tabular}

${ }^{*}$ Mann Whitney U test; M=Medijan; IR=interkvartilin raspon

Od ukupnog broja ispitanika, 67,1 \% su žene, a $32,9 \%$ muškarci. S nepotpunom osnovnom školom je 32,9 \% ispitanika, osnovnu školu ili srednju ima završenu $60 \%$ ispitanika, dok samo 7,1 \% ispitanika je sa završenom visokom školom ili fakultetom, raspodjela ispitanika po razini obrazovanja prema ustanovi u kojoj borave je značajna (Fisherov egzaktni test, $\mathrm{p}<0,001)$ (Tablica 2).

Tablica 2. Sociodemografske karakteristike ispitanika

\begin{tabular}{|c|c|c|c|}
\hline & \multicolumn{2}{|l|}{ Skupine } & \multirow{2}{*}{$p^{*}$} \\
\hline & Dom za starije i nemoćne & Dječji dom Klasje & \\
\hline \multicolumn{4}{|l|}{ Spol; N (\%) } \\
\hline Žene & $32(71,1)$ & $15(60)$ & \multirow{2}{*}{0,428} \\
\hline Muškarci & $13(28,9)$ & $10(40)$ & \\
\hline \multicolumn{4}{|l|}{ Razina obrazovanja; N (\%) } \\
\hline Nepotpuna osnovna škola & $15(33,3)$ & $8(32)$ & \multirow{4}{*}{$<0,001$} \\
\hline Osnovna škola & $5(11,1)$ & $16(64)$ & \\
\hline Srednja škola & $20(44,4)$ & $1(4)$ & \\
\hline Visoka škola ili fakultet & $5(11,1)$ & 0 & \\
\hline
\end{tabular}

*Fisherov egzaktni test

Razlog smještaja u ustanovu za ispitanike iz Doma za starije i nemoćnije za $44,4 \%$ ispitanika samoća, za $26,7 \%$ starost, a za $11,1 \%$ ispitanika zdravstveni razlozi. U Dječjem domu Klasje, najčešći razlog smještaja u ustanovu je za $36 \%$ ispitanika ili zanemarivanje i zlostavljanje od strane roditelja ili nemogućnost ili neodgovarajuća skrb roditelja za djecu. Po $4 \%$ ispitanika je u ustanovi zbog smrti, bolesti ili ovisnosti roditelja te ako je dijete zatečeno bez nadzora i u skitnji. $16 \%$ ispitanika su u ustanovi zbog loših rezultata u školi (Slika 1). 


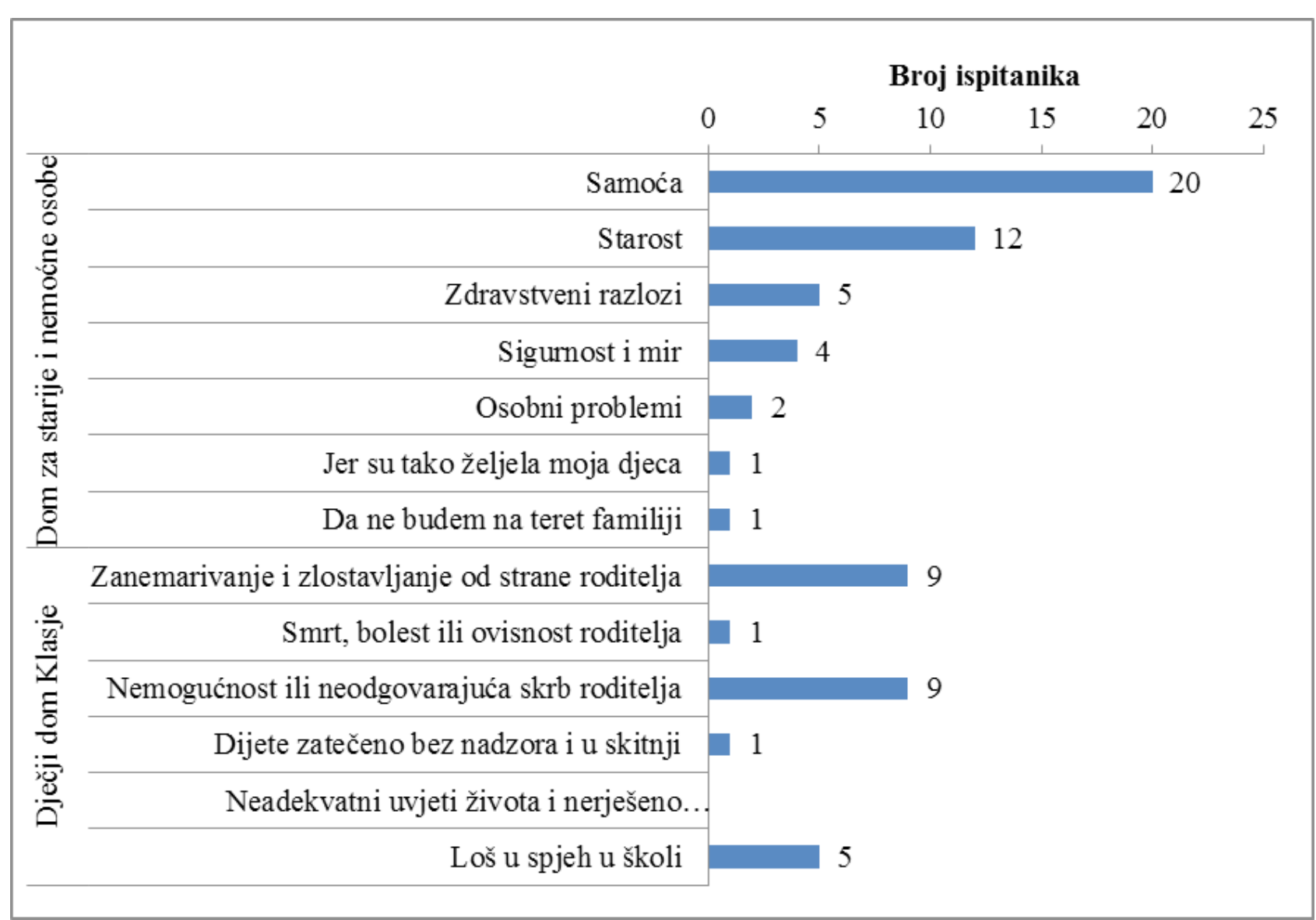

Slika 1. Razlog smještaja ispitanika prema vrsti ustanove u kojoj su smješteni

\section{Rezultati dobiveni na temelju skale usamljenosti (R-UCLA- Russsel, 1996)}

Skala usamljenosti kroz dvadeset pitanja daje uvid u usamljenost kod ispitanika s obzirom na ustanovu u kojoj su smješteni. U skladnim odnosima s ljudima oko sebe je 49,3\% ispitanika, za 41,2 \% ispitanika ponekad nedostaje društvo, njih $13 \%$ često nema nikoga kome bi se mogli obratiti, dok $41,2 \%$ ispitanika rijetko nema osjećaj usamljenosti. Najviše ispitanika 53,6 \% ima grupu prijatelja kojima pripada. Između ispitivanih skupina nije nađeno statistički značajne razlike ni u jednom odgovoru 1.do 5. Pitanja R-UCLA skale. (Tablica 3a).
Tablica 3a. Rezultati R-UCLA skale prema vrsti ustanove u kojoj su smješteni ispitanici (1. do 5. pitanje)

\begin{tabular}{|c|c|c|c|}
\hline & \multicolumn{2}{|c|}{ Skupine } & \multirow[b]{2}{*}{$p^{*}$} \\
\hline & $\begin{array}{c}\text { Dom za starije i } \\
\text { nemoćne }\end{array}$ & $\begin{array}{l}\text { Dječji dom } \\
\text { Klasje }\end{array}$ & \\
\hline $\begin{array}{l}\text { U skladnim sam odnosima s ljudima oko } \\
\text { sebe; N (\%) }\end{array}$ & & & 0,600 \\
\hline Nikada & $1(2,2)$ & $1(4,2)$ & \\
\hline Rijetko & $9(20)$ & $3(12,5)$ & \\
\hline Ponekad & $15(33,3)$ & $6(25)$ & \\
\hline Često & $20(44,4)$ & $14(58,3)$ & \\
\hline Nedostaje mi društvo; N (\%) & & & 0,356 \\
\hline Nikada & $6(13,3)$ & $4(17,4)$ & \\
\hline Rijetko & $15(33,3)$ & $3(13)$ & \\
\hline Ponekad & $17(37,8)$ & $11(47,8)$ & \\
\hline Često & $7(15,6)$ & $5(21,7)$ & \\
\hline $\begin{array}{l}\text { Nema nikoga kome bi se mogan } \\
\text { obratiti; N (\%) }\end{array}$ & & & 0,524 \\
\hline Nikada & $9(20)$ & $8(33,3)$ & \\
\hline Rijetko & $16(35,6)$ & $5(20,8)$ & \\
\hline Ponekad & $14(31,1)$ & $8(33,3)$ & \\
\hline Često & $6(13,3)$ & $3(12,5)$ & \\
\hline
\end{tabular}


Železnik D, Kanisek R, Železnik U. Usporedba usamljenosti adolescenata i starijih osoba u ustanovama socijalne skrbi. Zdravstveni glasnik. 2016;2: 14-26.

\begin{tabular}{|c|c|c|c|}
\hline & \multicolumn{2}{|c|}{ Skupine } & \multirow[b]{2}{*}{$p^{*}$} \\
\hline & $\begin{array}{l}\text { Dom za starije i } \\
\text { nemoćne }\end{array}$ & $\begin{array}{l}\text { Dječji dom } \\
\text { Klasje }\end{array}$ & \\
\hline Nemam osjećaj usamljenosti; N (\%) & & & 0,758 \\
\hline Nikada & $4(9,1)$ & $2(8,3)$ & \\
\hline Rijetko & $20(45,5)$ & $8(33,3)$ & \\
\hline Ponekad & $9(20,5)$ & $7(29,2)$ & \\
\hline Često & $11(25)$ & $7(29,2)$ & \\
\hline $\begin{array}{l}\text { Imam grupu prijatelja kojima pripadam; } \\
\text { N (\%) }\end{array}$ & & & 0,239 \\
\hline Nikada & $1(2,2)$ & 0 & \\
\hline Rijetko & $8(17,8)$ & $1(4,2)$ & \\
\hline Ponekad & $15(33,3)$ & $7(29,2)$ & \\
\hline Često & $21(46,7)$ & $16(66,7)$ & \\
\hline
\end{tabular}

*Fisherov egzaktni test

U ukupnom uzorku 18,6 \% ispitanika navelo je da rijetko imaju mnogo zajedničkog s ljudima oko sebe bez razlike prema ustanovi. Od ukupno 39,1 \% ispitanika koji navode da često više nisu ni s kim bliski, statistički značajno ih je više iz Doma za starije i nemoćne (Fisherov egzaktni test, $\mathrm{p}=0,006$ ). Da njihove interese i ideje često ne dijele ljudi oko njih, navodi $24,6 \%$ ispitanika, od kojih statistički učestalije ispitanici iz Doma za starije i nemoćne (Fisherov egzaktni test, $\mathrm{p}=0,026)$. Veći dio $78,3 \%$, ispitanika je ponekad ili često otvorena osoba, da su bliski s nekim osobama ističe $41,4 \%$ ispitanika, podjednako iz obje ustanove (Tablica $3 b$ ).

Tablica 3b. Rezultati R-UCLA skale prema vrsti ustanove u kojoj su smješteni ispitanici (6. do 10. pitanje)

\begin{tabular}{|c|c|c|c|}
\hline & \multicolumn{2}{|c|}{ Skupina } & \multirow[b]{2}{*}{$p^{*}$} \\
\hline & $\begin{array}{l}\text { Dom za starije i } \\
\text { nemoćne }\end{array}$ & $\begin{array}{l}\text { Dječij dom } \\
\text { Klasje }\end{array}$ & \\
\hline $\begin{array}{l}\text { Imam mnogo zajedničkog s ljudima } \\
\text { oko sebe; N (\%) }\end{array}$ & & & 0,163 \\
\hline Nikada & $1(2,2)$ & $3(12)$ & \\
\hline Rijetko & $11(24,4)$ & $2(8)$ & \\
\hline Ponekad & $20(44,4)$ & $12(48)$ & \\
\hline Često & $13(28,9)$ & $8(32)$ & \\
\hline Više ni s kim nisam blizak; N (\%) & & & 0,006 \\
\hline Nikada & $7(15,6)$ & $13(54,2)$ & \\
\hline Rijetko & $22(48,9)$ & $5(20,8)$ & \\
\hline Ponekad & $7(15,6)$ & $4(16,7)$ & \\
\hline Često & $9(20)$ & $2(8,3)$ & \\
\hline $\begin{array}{l}\text { Moje interese i ideje ne dijele ljudi } \\
\text { oko mene; N (\%) }\end{array}$ & & & 0,026 \\
\hline
\end{tabular}

\begin{tabular}{lcc}
\hline & \multicolumn{2}{c}{ Skupina } \\
\cline { 2 - 3 } & $\begin{array}{c}\text { Dom za starije i } \\
\text { nemóne }\end{array}$ & $\begin{array}{c}\text { Dječji dom } \\
\text { Klasje }\end{array}$ \\
\hline Nikada & $1(2,2)$ & $2(8,3)$ \\
\hline Rijetk0 & $8(17,8)$ & $11(45,8)$ \\
\hline Ponekad & $22(48,9)$ & $8(33,3)$ \\
\hline Često & $14(31,1)$ & $3(12,5)$ \\
\hline Otvorena sam osoba; N (\%) & & \\
\hline Nikada & $1(2,2)$ & $3(12,5)$ \\
\hline Rijetko & $9(20)$ & $2(8,3)$ \\
\hline Ponekad & $21(46,7)$ & $7(29,2)$ \\
\hline Često & $14(31,1)$ & $12(50)$ \\
\hline S nekim ljudima sam blizak; N (\%) & & \\
\hline Nikada & $1(2,2)$ & $1(4)$ \\
\hline Rijetko & $9(20)$ & $3(12)$ \\
\hline Ponekad & $18(40)$ & $9(36)$ \\
\hline Često & $17(37,8)$ & $12(48)$ \\
\hline *Fisherov egzaktni test & &
\end{tabular}

U ukupnom uzorku 17,1 \% ispitanika navodi da ih često ne primaju u svoje društvo, od kojih statistički značajno učestalije ispitanici Dječjeg doma Klasje (Fisherov egzaktni test, $\mathrm{p}=0,003$ ). Često su društveni odnosi površni za 11,6 \% ispitanika, a da ih nitko stvarno ne poznaje dobro smatra $20 \%$ ispitanika, bez značajne razlike prema ustanovama. Ponekad i često se osjeća izolirano od drugih ljudi 9,1\% ispitanika statistički značajno učestalije iz Doma za starije i nemoćne (Fisherov egzaktni test, $\mathrm{p}<0,001$ ). U ukupnom uzorku 58,6 \% ispitanika navelo je da kad žele društvo često ga mogu naći statistički značajno učestalije 72 \% iz Dječjeg doma Klasje (Fisherov egzaktni test, $\mathrm{p}=0,048$ ) (Tablica 3c).

Tablica 3c. Rezultati R-UCLA skale prema vrsti ustanove u kojoj su smješteni ispitanici (11. do 15. pitanje)

\begin{tabular}{|c|c|c|c|}
\hline & \multicolumn{2}{|c|}{ Skupina } & \multirow[b]{2}{*}{$p^{*}$} \\
\hline & $\begin{array}{l}\text { Dom za starije i } \\
\text { nemoćne }\end{array}$ & Dječji dom Klasje & \\
\hline $\begin{array}{l}\text { Ljudi me ne primaju u svoje } \\
\text { društvo; N (\%) }\end{array}$ & & & 0,003 \\
\hline Nikada & $7(15,6)$ & $6(24)$ & \\
\hline Rijetko & $26(57,8)$ & $4(16)$ & \\
\hline Ponekad & $8(17,8)$ & $7(28)$ & \\
\hline Često & $4(8,9)$ & $8(32)$ & \\
\hline $\begin{array}{l}\text { Moji su društveni odnosi } \\
\text { površni; N (\%) }\end{array}$ & & & 0,627 \\
\hline
\end{tabular}


Železnik D, Kanisek R, Železnik U. Usporedba usamljenosti adolescenata i starijih osoba u ustanovama socijalne skrbi. Zdravstveni glasnik. 2016;2: 14-26.

\begin{tabular}{|c|c|c|c|}
\hline & \multicolumn{2}{|c|}{ Skupina } & \multirow[b]{2}{*}{$p^{*}$} \\
\hline & $\begin{array}{l}\text { Dom za starije i } \\
\text { nemoćne }\end{array}$ & Dječji dom Klasje & \\
\hline Nikada & $7(15,6)$ & $4(16,7)$ & \\
\hline Rijetko & $15(33,3)$ & $9(37,5)$ & \\
\hline Ponekad & $16(35,6)$ & $10(41,7)$ & \\
\hline Često & $7(15,6)$ & $1(4,2)$ & \\
\hline $\begin{array}{l}\text { Nitko me stvarno ne poznaje } \\
\text { dobro; } \mathrm{N}(\%)\end{array}$ & & & 0,087 \\
\hline Nikada & $3(6,7)$ & $7(28)$ & \\
\hline Rijetko & $11(24,4)$ & $7(28)$ & \\
\hline Ponekad & $21(46,7)$ & $7(28)$ & \\
\hline Često & $10(22,2)$ & $4(16)$ & \\
\hline $\begin{array}{l}\text { Osjećam se izoliranim od } \\
\text { drugih; N (\%) }\end{array}$ & & & $<0,001$ \\
\hline Nikada & $6(13,3)$ & $17(70,8)$ & \\
\hline Rijetko & $18(40)$ & $1(4,2)$ & \\
\hline Ponekad & $15(33,3)$ & $3(12,5)$ & \\
\hline Često & $6(13,3)$ & $3(12,5)$ & \\
\hline $\begin{array}{l}\text { Kada želim društvo mogu ga } \\
\text { naći; N (\%) }\end{array}$ & & & 0,047 \\
\hline Nikada & $1(2,2)$ & 0 & \\
\hline Rijetko & $9(20)$ & 0 & \\
\hline Ponekad & $12(26,7)$ & $7(28)$ & \\
\hline Često & $23(51,1)$ & $18(72)$ & \\
\hline
\end{tabular}

U ukupnom uzorku 38,6 \% ispitanika navodi, da ponekad postoje ljudi koji ih stvarno razumiju, statistički značajno učestalije 53,3 \% iz Doma za starije i nemoćne (Fisherov egzaktni test, $\mathrm{p}=0,001$ ).

Ispitanici iz Dječjeg doma Klasje, statistički značajno učestalije $68 \%$ su odgovorili da često ima ljudi s kojima mogu razgovarati. U ukupnom uzorku $72 \%$ ispitanika navodi, da često ima ljudi kojima se mogu obratiti (Fisherov egzaktni test, $\mathrm{p}=0,008)(\mathrm{Ta}-$ blica 3d).

Tablica 3d. Rezultati R-UCLA skale prema vrsti ustanove u kojoj su smješteni ispitanici (16. do 20. pitanje)

\begin{tabular}{lcc}
\hline & \multicolumn{2}{c}{ Skupina } \\
\cline { 2 - 3 } & $\begin{array}{c}\text { Dom za starije i } \\
\text { nemoćne }\end{array}$ & $\begin{array}{c}\text { Dječji dom } \\
\text { Klasje }\end{array}$ \\
\hline $\begin{array}{l}\text { Postoje lijudi koji me stvarno } \\
\text { razumiju; } N(\%)\end{array}$ & & 0,001 \\
\hline Nikada & $1(2,2)$ & 0 \\
\hline Rijetko & $4(8,9)$ & $2(8)$ \\
\hline Ponekad & $24(53,3)$ & $3(12)$ \\
\hline Često & $16(35,6)$ & $20(80)$ \\
\hline
\end{tabular}

\begin{tabular}{|c|c|c|c|}
\hline & \multicolumn{2}{|c|}{ Skupina } & \multirow[b]{2}{*}{$p^{*}$} \\
\hline & $\begin{array}{l}\text { Dom za starije i } \\
\text { nemoćne }\end{array}$ & $\begin{array}{l}\text { Dječji dom } \\
\text { Klasje }\end{array}$ & \\
\hline $\begin{array}{l}\text { Nesretan sam što sam tako } \\
\text { povučen; } \mathrm{N}(\%)\end{array}$ & & & 0,065 \\
\hline Nikada & $11(24,4)$ & $11(45,8)$ & \\
\hline Rijetko & $21(46,7)$ & $4(16,7)$ & \\
\hline Ponekad & $7(15,6)$ & $6(25)$ & \\
\hline $\begin{array}{l}\text { Često } \\
\end{array}$ & $6(13,3)$ & $3(12,5)$ & \\
\hline $\begin{array}{l}\text { Ljudi su oko mene, ali ne sa mnom; } \\
\text { N (\%) }\end{array}$ & & & 0,805 \\
\hline Nikada & $6(13,3)$ & $5(20,8)$ & \\
\hline Rijetko & $18(40)$ & $9(37,5)$ & \\
\hline Ponekad & $13(28,9)$ & $5(20,8)$ & \\
\hline $\begin{array}{l}\text { Često } \\
\end{array}$ & $8(17,8)$ & $5(20,8)$ & \\
\hline $\begin{array}{l}\text { Ima ljudi s kojima mogu } \\
\text { razgovarati; N (\%) }\end{array}$ & & & 0,008 \\
\hline Rijetko & $8(17,8)$ & 0 & \\
\hline Ponekad & $22(48,9)$ & $8(32)$ & \\
\hline $\begin{array}{l}\text { Često } \\
\end{array}$ & $15(33,3)$ & $17(68)$ & \\
\hline $\begin{array}{l}\text { Ima ljudi kojima se mogu obratiti; } \\
\text { N (\%) }\end{array}$ & & & 0,023 \\
\hline Rijetko & $6(13,3)$ & $1(4)$ & \\
\hline Ponekad & $22(48,9)$ & $6(24)$ & \\
\hline Često & $17(37,8)$ & $18(72)$ & \\
\hline
\end{tabular}

Osjećaj usamljenosti ocijenjen je zbrojem svih odgovora R-UCLA skale. Raspon ocjene se kreće od 20 do 80, gdje veća ocjena označava veći stupanj usamljenosti. Srednja vrijednost ocjene usamljenosti svih ispitanika je 41 (interkvartilnog raspona 34,8 - 49,3). Statistički značajno više su usamljeni ispitanici iz Doma za starije i nemoćne, u odnosu na ispitanike iz Dječjeg doma Klasje (Mann Whitney test, $\mathrm{p}=0,028$ ) (Tablica 4).

Tablica 4. Srednja ocjena skale usamljenosti prema vrsti ustanove u kojoj su smješteni ispitanici

\begin{tabular}{|c|c|c|c|}
\hline & \multicolumn{2}{|c|}{ Skupina } & \multirow{2}{*}{$p^{*}$} \\
\hline & Dom za starije i nemoćne & Dječji dom Klasje & \\
\hline Skala usamljenosti; M (IR) & $43(37-53)$ & $38(34-45,5)$ & 0,028 \\
\hline \multicolumn{4}{|c|}{ *Mann Whitney U test; M=Medijan; IR=interkvartilni raspon } \\
\hline \multicolumn{4}{|c|}{$\begin{array}{l}\text { Nešto je veća usamljenost muškaraca u odnosu } \\
\text { na žene, ali bez statistički značajne razlike prema vr- } \\
\text { sti ustanove (Tablica } 5 \text { ). }\end{array}$} \\
\hline
\end{tabular}


Tablica 5. Srednja ocjena skale usamljenosti prema spolu te vrsti ustanove u kojoj su smješteni ispitanici.

\begin{tabular}{lccc}
\hline \multirow{2}{*}{ Skala usamljenosti; M (IR) } & \multicolumn{2}{c}{ Skupina } & \\
\cline { 2 - 3 } & Dom Za starije i nemoćne & Dječji dom Klasje & \\
\hline Žene & $43(35,3-51)$ & $38(34-46)$ & 0,110 \\
\hline Muškarci & $44(40,5-58)$ & $38(34,3-45,3)$ & 0,136 \\
\hline${ }^{*}$ Mann Whitney test; M=Medijan; IR=interkvartilni raspon & &
\end{tabular}

Najmanje usamljeni su oni ispitanici koji su u Dom za starije i nemoćne došli zbog sigurnosti i mira. U Dječjem domu Klasje najmanje su usamljeni oni koji su u ustanovi zbog lošeg uspjeha u školi (Tablica 6).

Tablica 6. Srednja ocjena skale usamljenosti prema razlogu smještaja u ustanovu

\begin{tabular}{|c|c|c|c|c|}
\hline \multicolumn{2}{|c|}{ Razlog smještaja u ustanovu } & $\mathrm{N}$ & $M(I R)$ & $p^{*}$ \\
\hline \multirow{7}{*}{$\begin{array}{l}\text { Dom za } \\
\text { starije i } \\
\text { nemoćne } \\
\text { osobe }\end{array}$} & Samoća & 20 & $43(38,5-50,5)$ & 0,283 \\
\hline & Starost & 12 & $44(36-59)$ & \\
\hline & Zdravstveni razlozi & 5 & $45(33,5-48,5)$ & \\
\hline & Sigurnost i mir & 4 & $35,5(28,7-52)$ & \\
\hline & Osobni problemi & 2 & 60,5 & \\
\hline & Jer su tako željela moja djeca & 1 & 55 & \\
\hline & Da ne budem na teret familiji & 1 & 31 & \\
\hline \multirow{6}{*}{$\begin{array}{l}\text { Dječji dom } \\
\text { Klasje }\end{array}$} & $\begin{array}{l}\text { Zanemarivanje i zlostavljanje od } \\
\text { strane roditelja }\end{array}$ & 9 & $38(34-44,5)$ & 0,208 \\
\hline & Smrt, bolest ili ovisnost roditelja & 1 & 53 & \\
\hline & $\begin{array}{l}\text { Nemogućnost ili neodgovarajuća } \\
\text { skrb roditelja }\end{array}$ & 9 & $36(31-42)$ & \\
\hline & $\begin{array}{l}\text { Dijete zatečeno bez nadzora i u } \\
\text { skitnji }\end{array}$ & 1 & 50 & \\
\hline & $\begin{array}{l}\text { Neadekvatni uvjeti života i } \\
\text { neriješeno stambeno pitanje u } \\
\text { obitelji }\end{array}$ & 0 & $\cdot$ & \\
\hline & Loš uspjeh u školi & 5 & $37(32-42)$ & \\
\hline
\end{tabular}

\section{*Kruskal Wallis test}

Nema značajne povezanosti između vremena provedenog u ustanovi i ocjene usamljenosti, kako za sve ispitanike $\rho=0,015 ., p=0,906)$, tako ni kod ispitanika Doma za starije i nemoćne $\rho=0,008$., $\mathrm{p}=0,958)$, niti kod ispitanika iz Dječjeg doma Klasje $\rho=-0,177 ., p=0,396)$.

\section{RASPRAVA}

Usamljenost je fenomen koji se može javiti u svim razdobljima ljudskog života ali je najznačajniji i najuočljiviji kod adolescenata i starijih osoba.
U svjetskoj relevantnoj literaturi postoje različiti rezultati.

$\mathrm{U}$ prethodnim istraživanjima nađene su korelacije između usamljenosti i fizičkog funkcioniranja $(15,16,18,20,26,29,31,38)$. Pronađena je i korelacija između usamljenosti i smanjene tjelesne aktivnosti (32). Utvrđeno je i da je usamljenost u starosti, a osobito emocionalna usamljenost, u korelaciji sa samopoštovanjem kao i drugim psihološkim faktorima, uključujući životno zadovoljstvo $(2,33-$ $36,39,40)$. Starija životna dob sama po sebi predstavlja čimbenik rizika za pojavu usamljenosti te ju zbog toga treba ozbiljno i shvatiti. Ne treba ni zaboraviti da moguće posljedice usamljenosti mogu dovesti do zdravstvenih problema, ponajprije do depresije $(21,36)$.

Glavni problem smještaja u dom za starije i nemoćne je u činjenici da je starija osoba izdvojena iz svoje fizičke i socijalne sredine koja može biti razlog pojave usamljenosti. Zbog toga je prilikom smještaja u ustanovu potreban prvenstveno njen dobrovoljni pristanak (37).

$\mathrm{Na}$ socijalnu usamljenost adolescenta mogu utjecati značajke okoline, kao i neke njegove osobne značajke zbog kojih se rjeđe sklapaju čvrsta prijateljstva među adolescentima (41). Ovim istraživanjem pokušali smo utvrditi jesu li i koliko usamljeni adolescenti i starije osobe koje su smještene u ustanove socijalne skrbi. Smještaj adolescenata u ustanovu nije dobrovoljan već su tamo smješteni rješenjem Centra za socijalni rad, pa je najčešći razlog dolaska zanemarivanje i zlostavljanje od strane roditelja i nemogućnost ili neodgovarajuća skrb roditelja za djecu. Starije osobe ,naravno ne sve, u ustanove dolaze dobrovoljno a najčešći razlozi su samoća, usamljenost, starost i zdravstveni razlozi.

Utvrdili smo, da je najčešći razlog smještaja kod ispitanika Doma za starije i nemoćne osobe samoća. Drugi razlog je starost što ne čudi jer su u ustanovi smještene osobe visoke životne dobi. Ne treba zanemariti ni zdravstveni razlog jer starije osobe boluju od jedne ili više kroničnih bolesti, a u ustanovi postoji medicinsko osoblje koje je osobama starije dobi dostupno 24 sata, zatim signalizacija s kojom je 
svaka soba povezana s ambulantom, a i liječnik opće medicine koji u ustanovu dolazi svaki dan.

U Dječjem domu Klasje najčešći razlog smještaja je zanemarivanje i zlostavljanje od strane roditelja, nemogućnost ili neodgovarajuća skrb roditelja za djecu, dok su ostali većinom smješteni zbog lošeg uspjeha u školi.

Najveći broj korisnica ustanova odgovorio je da „Nema nikoga kome bi se mogao obratiti“, što ide u prilog činjenici da u ustanovama treba više stručnog i medicinskog osoblja kojima bi se mogli obratiti.

Značajno više korisnika iz Doma za starije i nemoćne osobe nego adolescenata iz Dječjeg doma Klasje odgovorilo je, da nemaju bliskih osoba. Korisnici starije dobi smješteni su u jednokrevetnim sobama i jedino zajedničko što imaju sa drugima korisnicima je to što su smješteni u istoj ustanovi, međusobno se ne poznaju, teže sklapaju prijateljstva, a određeni dio njih ne teži ka bližem međusobnom upoznavanju s drugim korisnicima pa tako ni prijateljstvu. Pored toga dešava se da stariji ljudi žele biti sami, razmišljati u samoći, i pritom se ne osjećaju usamljeno ili izolirano, jer koriste svoje vrijeme za samostalni kreativni rad, odmor od drugih ljudi ili stresa i uživaju u odvojenosti od drugih. Samoću su sami odabrali, dok usamljenost ne biraju vlastitom voljom što ih ispunjava subjektivnim osjećajem praznine.

Adolescenti su smješteni u svojoj ustanovi u zajednici (djevojčice i dječaci odvojeno) i svatko od njih čini malu zajednicu za koju se brine (čišćenje, spremanje, održavanje, kuhanje i dr.), pod nadzorom odgajatelja. Spavaonica im je zajednička kao i ostali prostor koji dijele i o kojem se brinu, tako da ne čudi i da su više međusobno bliski od starijih osoba.

Što se tiče osobnih značajki, socijalnoj usamljenosti skloniji su oni adolescenti koji imaju niže samopoštovanje, koji su povučeniji, sramežljiviji, anksiozniji i općenito osjetljiviji, kao i oni koji imaju općenito pesimističan pogled na sebe i na svijet $(27,42)$.

Statistički značajna razlika pronađena je i u tvrdnji „Moje interese i ideje ne dijele ljudi oko mene"gdje su najveći dio odgovora ponekad i često odgovorile starije osobe. Dom za starije i nemoćne osobe nudi korisnicima svojih usluga radnu terapiju sa različitim sadržajima (grupni sastanci korisnika, individualni razgovori i aktivnosti, posuđivanje knjiga, društvene igre, izleti korisnika, čitanje poezije, obilježavanje vjerskih i državnih blagdana, druženja uz harmonikaša, jutarnja gimnastika i dr.), međutim unatoč tome veoma se mali broj korisnika uključuje $\mathrm{u}$ te aktivnosti jer su nezainteresirani.

Statistički značajna razlika pronađena je i u tvrdnji „Ljudi me ne primaju u svoje društvo“, gdje je odgovor često navelo ukupno $17,1 \%$ korisnika od kojih je $32 \%$ adolescenata. Zašto je takav odgovor? $\mathrm{Na}$ adolescente, koji su smješteni u ustanovi često utječu i ranija negativna socijalna iskustva, traumatična iskustva iz svojih obitelji, nezadovoljstva socijalnih interakcija sa drugim vršnjacima iz svoje okoline i agresivna ponašanja dok svoje socijalne interakcije nalaze među vršnjacima koji su također smješteni u ustanovu.

Klarin je u svom istraživanju na osjećaju usamljenosti među adolescentima školske dobi došla do rezultata da usamljene osobe nemaju socijalne vještine nužne za interpersonalnu komunikaciju.

Kod korisnika Doma za starije i nemoćne pronađena je statistički značajna razlika u tvrdnji „Osjećam se izoliranim od drugih" (Fisherov egzaktni test $\mathrm{p}=<0,001)$. Najviše odgovora bilo je rijetko i ponekad u 73,3 \% ispitanika. Pronađena je statistički značajna razlika u tvrdnji „Kada želim društvo mogu ga naći “ jer su odgovore ponekad i često naveli svi korisnici Dječjeg doma Klasje.

Djeca koja imaju društvo i prijatelja najčešće koriste prosocijalno ponašanje koje je socijalno poželjno i koje je usmjereno na pomaganje drugima. Ostvarenim kvalitetnim socijalnim odnosima sa svojim vršnjacima imaju razvijene i socijalne vještine, spremniji su dijeliti i pomagati se međusobno. Takvo ponašanje je pozitivno, odnosno prihvaćeno $(41,42)$.

Stare osobe kod kuće većinom žive same, osjećaju se odbačenima, otuđenim, neshvaćenim, javlja se nedostatak socijalnih aktivnosti koje pružaju osjećaj bliskosti, ne žele biti djeci na teretu, češće zaboravljaju, teže se i sporije kreću a domovi za starije i nemoćne pružaju im osjećaj sigurnosti. U Domu 
za stare i nemoćne postoje osobe kojima se mogu obratiti ako imaju neki problem koji ne mogu sami riješiti (socijalni radnici), a ponajprije zdravstveno osoblje koji im je dostupno 24 sata a slobodno vrijeme imaju samo za sebe i mogu ga sami sebi prilagoditi (čitanje, šetnje, društvene igre, druženje uz kavu i dnevnu štampu, radna terapija i dr.). Zbog tih činjenica postoji statistički značajna razlika u tvrdnji „Postoje ljudi koji me stvarno razumiju“ u 53,3\% iz Doma za stare i nemoćne.

Značajno više ispitanika iz Dječjeg doma Klasje, odgovorilo je da ima ljudi s kojima mogu razgovarati. Već je ranije spomenuto da se za djecu u Dječjem domu Klasje brine veći broj različitog profesionalnog kadra koji im pruža nesebičnu pomoć u njihovom odrastanju. Također i sam razlog smještaja ove djece utječe na ovakav odgovor.

Najčešći odgovor ispitanika Dječjeg doma Klasje je da „Ima ljudi kojima se mogu obratiti“. Iako odvojeni od svoje obitelji, adolescenti ovdje dobivaju ono što kod svojih kuća nisu imali, a to je razumijevanje, pozitivnu socijalnu interakciju od zaposlenog osoblja, osjećaj pripadnosti, sigurnosti, brige, pažnje i prijateljstva. Bez obzira na razloge smještaja u ustanovu, adolescenti ovdje imaju socijalne veze i kvalitetu odnosa, a imaju nekoga kome se mogu obratiti.

\section{ZAKLJUČAK}

U današnje vrijeme, kada je u prvom planu neizravna komunikacija, usamljenost je došla u središte pozornosti i kod mladih i kod starih osoba. Zbog svojih specifičnih teškoća adolescenti se teško ili nikako ne uključuju u druge organizirane aktivnosti. To ih čini usamljenima, i takva ponašanja uzrokuju pad kvalitete života mladih.

Psihosocijalni utjecaji imaju ključnu ulogu u općem osjećanju mladih i starih ljudi u institucionalnoj skrbi, zbog toga je potrebno raditi na pitanjima i procesima kvalitete njihovih života u smislu uključenosti u socijalnu mrežu i osiguravanju uvjeta u kojima žive u svijetlu osobnih, kulturnih, vjerskih, etničkih i etičkih pogleda, kako bi se smanjila i sprječila usamljenost.

Psihosocijalni pristup naglašava životno zadovoljstvo, socijalnu interakciju i sudjelovanje te psihološke resurse, koji uključuju osobnu rast, tako da postoji potreba da se sadržaj za sprečavanje usamljenosti kod starijih i mlađih osoba integrira u obrazovanje stručnjaka za rad sa tim ljudima.

\section{LITERATURA}

1. Rok K. Reciprocity of Social Exchange and Social Satisfaction among Older Women Journal of Personality and Social Psychology. 1987;52(1):145154.

2. Golden J, Conroy R.M, Bruce I, Denihan A, Greene E, Kirby M. \& Lawlor BA. Loneliness, social support networks, mood and well-being in community-dwelling elderly. International Journal of Geriatric Psychiatry. 2009;24(7):694-700.

3. Uchino B.N. Social support and health: A review of physiological processes potentially underlying links to disease outcomes. Journal of Behavioral Medicine. 2006;29:377-387.

4. Shor E., Roelfs D. J. \& Yogev T. The strength of family ties: A meta-analysis and meta-regression of self-reported social support and mortality. Social Networks. 2013;35:626-638.

5. Holt-Lunstad J, Smit TB, Baker M, Harris T, Stephenson D. Loneliness and Social Isolation as Risk Factors for Mortality. A Meta-Analytic Review. Perspectives on Psychological Science March. 2015;10(2):227-237.

6. Ajduković M, Ručević S. Odnos depresivnosti, zdravlja i funkcionalne sposobnosti korisnika domova za starije i nemoćne osobe. Društvena istraživanja . Rev. soc. Polit. 2013; 20(2):149-165.

7. Asher SR, Hymel SH, Renshaw PD. Lonelines in Children. Child Development. 1984;55: 14561464.

8. Sullivan H.S. Interpersonal theory of Psychiatry. New York: W.W. Norton\& Company, Inc. 1953.

9. Padmaja G, Sushma B. Psychosocial problems and well being in institutionalized and non institutionalized children. Journal Of Humanities And Social Science. 2014;19(10):59-64.

10. Ford T, Vostanis P, Meltzer H, Goodman R. Psychiatric disorder among British children looked after by local authorities: comparison with chil- 
dren living in private household. The British Journal of Psychiatry. 2007;190:319-325.

11. Erol N, Simsek Z, Munir K. Mental health of adolescents reared in institutional care in Turkey: challenges and hope in the twenty-first century. European Child and Adolescent Psychiatry. 2010;19(2):113-124.

12.Zeanah CH, Smyke AT, Koga SF, Carlson E. The Bucharest Early Intervention Project Core Group. Attachment in Institutionalized and Community Children in Romania. Child Development, 2005;76(5):1015-1028.

13. Han E, Choi N. Korean institutionalized adolescents' attributions of success and failure in interpersonal relations and perceived loneliness. Children and Youth Services Review. 2006; 28 (5):535-547.

14. Ptacek R, Kuzelova H, Celedova L. Social and Emotional Loneliness in Children in Foster and Institutional Care. European Psychiatry. 2011;26(1):338 Abstracts of the 19th European Congress of Psychiatry.

15. Dell'Aglio DD, Hutz CS. Depression and school achievement of institutionalized children and adolescents. Psicologia: Reflexão e Crítica. 2004; 17(3):351-357.

16. Wathier JL, Dell'Aglio D D. Depressive symptoms and stressful events in children and adolescents in the institutionalized context. Revista de Psiquiatria do Rio Grande do Sul, 2007:29:3.

17. Duca GF, Silva SG, Thume E, Santos I, Hallal, PC. Predictive factors for institutionalization of the elderly: a case contol study. Rev Saude Publica. 2012;46(1):147-53.

18. Beeson RA. Loneliness and depression in spousal caregivers of those with Alzheimer's disease versus non-caregiving spouses . Archives of Psyschiatrich Nursing. 2003;17(3):135-143.

19. Klarin M. Uloga socijalne podrške vršnjaka i vršnjačkih odnosa u usamljenosti predadolescenata i adolescenata, Društvena istraživanja. 2004;13(74):1084-1097.

20. O'Luanaigh C, Lawlor BA. Loneliness and the health of older people. International Journal of Geriatric Psychiatry. 2008;23(12):1213-1221.
21.Heikkinen RL. \& Kauppinen M. Mental well-being: A 16-year follow-up among older residents in Jyvaskyla. Archives of Gerontology and Geriatrics. 2011;52(1):33-39.

22. Cohen-Mansfield J, Shmotkin D, Goldberg S. Loneliness in old age: Longitudinal changes and their determinants in an Israeli sample. International Psychogeriatrics. 2009;21(6):1160-1170.

23. Aartsen $M$, Jylhä M. Onset of loneliness in older adults: Results of a 28 year prospective study. European Journal of Ageing. 2011;8:31-38.

24. Dykstra PA, Van Tilburg TG, de Jong Gierveld J. Changes in older adult loneliness: Results from a seven-year longitudinal study. Research on Aging. 2005;27(6):725-747.

25. Newall NE, Chipperfield JG, Clifton RA, Perry RP, Swift AU, Ruthig JC. Causal beliefs, social participation, and loneliness among older adults: A longitudinal study. Journal of Social and Personal Relationships. 2009;26(2-3):273-290.

26. Dahlberg L, McKee KJ. Correlates of social and emotional loneliness in older people: evidence from an English community study. Aging Ment Health. 2014;18(4):504-514.

27. Wei HS. Friends can hurt you: Examining the coexistence of friendship and bullying among early adolescents. School Psychology International. 2011;32(3):244-262.

28. Laursen B, Hartl AC. Understanding loneliness during adolescence: developmental changes that increase the risk of perceived social isolation. J Adolesc. 2013;36(6):1261-8.

29. Rönkä AR, Rautio A, Koiranen M, Sunnari V, Taanila A. Experience of loneliness among adolescent girls and boys: Northern Finland Birth Cohort 1986 study. International Journal of Adolescence and Youth. 2016; Dostupno http://www. tandfonline.com/doi/full/10.1080/02673843.201 5.1136659 ;pristupljeno :13.8.2016

30. Russsel DW. UCLA Loneliness Scale ( Versio 3): reliability, validity, and factor structure. J Pers Assess. 1996;66(1):20-40.

31. Routasalo P, Pitkala KH. Loneliness among older people. Reviews in Clinical Gerontology. 2003;13:303-311. 
32. Netz Y, Goldsmith R, Shimony T, Arnon M, Zeev A. Loneliness is associated with an increased risk of sedentary life in older Israelis. Aging \& Mental Health. 2013;17(1):40-47.

33. Schoenmakers EC, Van Tilburg TG, Fokkema T. Coping with loneliness: What do older adults suggest? Aging \& Mental Health. 2012;16(3):353360.

34.Železnik D. Skrb zase kot paradigma življenja starostnikov: znanstvena monografija :[raziskava o pomenu skrbi zase pri starostnikih]. Slovenj Gradec: Visoka šola za zdravstvene vede, 2014. p.101.

35. Mhaolain AMN, Gallagher D, Connell H.O, Chin AV, Bruce I, Hamilton F, Lawlor BA. Subjective well-being amongst community-dwelling elders: What determines satisfaction with life? Findings from the Dublin Healthy Aging Study. International Psychogeriatrics. 2012;24(2):316-323.

36. Lovreković M, Leutar Z. Kvaliteta života osoba u domovima za starije i nemoćne osobe u Zagrebu. Socijalna ekologija, 2010;19:55-79.

37.Železnik D. 2010. Self-care behavior styles and the functional ability of elderly people living in their home environmenr Vedenjski stili samooskrbe in funkcionalne sposobnosti starostnikov $\mathrm{v}$ domačem okolju. Obzornik zdravstvene nege, 44(1):3-11.

38. Abot Okelo M. Loneliness Among Elderly people in Finnish health care institutions, Laurea University of Applied Sciences: Otaniemi. 2014.

39. Ahmad A., Altaf M. \& Jan K. 2016. Loneliness, Self Esteem and Depression among Elderly People of Kashmir. The International Journal of Indian Psychology.

40. Singh A. \& Misra N. Loneliness, depression and sociability in old age. Industrial Psychiatry Journal. 2009; 18(1):51-55.

41. Junttila, N, Vauras, M, Niemi PM, Laakkonen E. Multisource assessed social competence as a predictor for children's and adolescents' later loneliness, social anxiety, and social phobia. Journal for Educational Research Online, 2012;4:73-98.

42. Maričić J. Socijalna usamljenost adolescenata. Tesa, Psihološki centar. 2016; Dostupno: http:// www.tesa.hr/izazovi-roditeljstva/socijalna-usamljenost-adolescenata/ pristupljeno 14.8.2016. 


\title{
THE COMPARISON OF LONELINESS IN ADOLESCENTS AND ELDERLY IN SOCIAL CARE INSTITUTIONS
}

\author{
Danica Železnik ${ }^{1,2}$, Ružica Kanisek ${ }^{3}$, Uroš Železnik ${ }^{1,4}$ \\ ${ }^{1}$ University College of Health Sciences Slovenj Gradec, Slovenia \\ ${ }^{2}$ Alma Mater Europaea, ECM, Slovenia \\ ${ }^{3}$ Nursing Home Osijek, Croatia \\ ${ }^{4}$ Medical Center Ptuj, Slovenia
}

\begin{abstract}
INTRODUCTION: Loneliness is often described as unpleasant, painful, or anxious need for another person or people. This experience, to a greater or lesser extent, is fundamental to all people at some stage of our lives.

OBJECTIVE: The objective of this research is to determine whether there are differences in the perception of loneliness among adolescents placed in an institution for children and young people and the elderly accommodated in social care institutions.

SUBJECTS AND METHODS: The research included a total of 70 patients, 25 of which were users of the Children's Home Klasje in Osijek, ages 12 to 20, and 45 users of The Home for Elderly and Disabled also in Osijek, age 67 and over. An anonymous questionnaire was used as the research instrument. The differences between loneliness ratings per establishment were tested with a Mann Whitney test and accommodation reasons by a Kruskal Wallis test.

RESULTS: Out of the total number of patients tested, $67.1 \%$ were women, and $32.9 \%$ men. $32.9 \%$ of the patients have incomplete primary education, $60 \%$ of them have either completed secondary or primary education, and only $7.1 \%$ of the respondents have university education. Results indicate that the biggest difference between the two groups is manifested through social support and quality of relationships between groups, and less through the emotional aspect.

DISCUSSION AND CONCLUSIONS: The research results show that there is less loneliness among adolescents than the elderly in institutions. The focus of this research would be that more attention should be paid to the individual needs of young people and the elderly in order to include them into programs best suited for their needs.
\end{abstract}

Key words: adolescents, elderly, loneliness

Correspondence:

Professor Danica Zeleznik. MD, PhD

zeleznik.danica@gmail.com 